
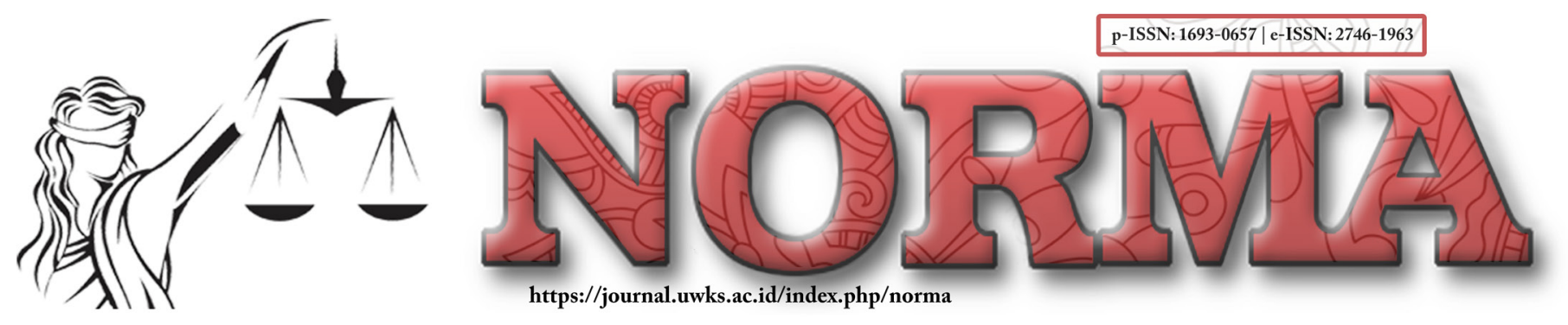

\title{
Judges' Ratio Decidendi in Marriage Dispensation Case at The Gresik Religious Court Regarding Marriage Age Limit
}

\author{
Dewi Murniati \\ Lawyer at Dewi and Partners \\ e-Mail: dewi83.advokat@gmail.com
}

\begin{abstract}
:
This study discusses the Marriage Age Limit Provisions According to Law Number 1 of 1974 concerning Marriage (Case Study in the Gresik Religious Court), this research is based on the number of divorce cases in the Gresik Religious Court, which are still dominated by productive age, Seeing the phenomenon, those who generally immature, not adequately prepared to enter the world of marriage, the marriage dispensation granted in a religious court on the lives of those who are married has both positive and negative effects. The positive impact of preventing adultery is that the opposing side is prone to disputes because those relatively young certainly have different thoughts from those who have grown up. This study examines and analyses the age limit's application for marriage and analyses the judges' considerations in examining and determining marital dispensation cases in the Gresik Religious Court. To answer the problem, the writer uses sociolegal research methods. The data used were sourced from legislation, literature study, and scholars' opinions and data obtained from the Gresik Religious Court. The study results show that applying the age limit for marriage is less practical or cannot be fully used to the people in the Gresik Religious Court's jurisdiction. This is indicated by the high number of marriage dispensation requests in the Gresik Religious Court. Secondly, the Judge's consideration in examining the case for a marriage dispensation request at the Gresik Religious Court was under the procedures set out in Perma Number 5/2019.
\end{abstract}

Keywords: Marriage; Dispensation; Age

\section{Article's History: \\ Received: \\ 19 November, 2020;}

Received in revised form:

13 December, 2020;

Accepted:

15 January, 2021;

Published:

15 January, 2021.

DOI:

10.30742/nlj.v17i3.1089

\section{INTRODUCTION}

Marriage is a sacred bond between a man and a woman, which has been regulated in Islamic Law and laws because, from this marriage, a person can maintain his selfrespect and keep away from slander. By marriage, one has also practised half of his religion because many rewards cannot be obtained when single or living alone in a marriage. Thus, it is highly recommended for someone who can hasten marriage.

According to the law, marriage in Indonesia is legal as long as it is carried out according to the religion or belief provisions and does not conflict with the prevailing rules and regulations. Among the marriage requirements that apply in Indonesia according to the Marriage Law are related to the age of marriage, namely that the 
prospective groom is only allowed to enter into a marriage as long as he has reached the age of 19 (nineteen) years and the future bride has reached the age of 19 (sixteen) years. According to the law, marriage in Indonesia is legal as long as it is carried out according to the religion or belief provisions and does not conflict with the applicable laws and regulations. Among the marriage requirements that apply in Indonesia according to the Marriage Law are related to the age of marriage, that is, the prospective groom is only allowed to marry as long as he has reached the age of 19 (nineteen) years and the future bride has reached the age of 19 (sixteen) years. ${ }^{1}$

With the existence of an age limit regulated in the law as mentioned above, of course, it is to limit the occurrence of early marriage. The two candidates who are going to marry are still under age stipulated by law. If irregularities occur in society, the parties concerned can apply for or ask for dispensation to the Court or other official appointed by the parents of both male and female parties. Based on Article 7 of the Marriage Law's provisions, if there is a deviation from the aforementioned marital age requirements, the new marriage can occur after receiving a Court's dispensation.

Applications for dispensation of marriage at the Gresik Religious Court in 2019 are 97 (ninety-seven) applications. ${ }^{2}$ The high number of applications for marriage dispensation at the Gresik Religious Court in 2019 is directly proportional to the high divorce rate at the Gresik Religious Court in the first quartal of 2019, according to Emi Rumhastuti, Junior Registrar of the Law of the Gresik Religious Court published on online media pages, most of the divorces are triggered by factors economy as many as 459 (four hundred and fifty-nine) cases. The constant dispute factor was 237 (two hundred thirty-seven) cases, and the domestic violence factor (KDRT) was 154 (one hundred and fifty-four) cases. Productive ages still dominate divorce cases at the Gresik Religious Court, with an average of 22 (twenty-two) years to 39 (thirty-nine) years. According to Emi Rumhastuti, at that age, it can be said that she is vulnerable to not having a mature relationship with her household.

Seeing the phenomenon mentioned above, it can be concluded that generally, immature individuals are not ready to enter the marriage world. They typically marry at a relatively young age and think that it is still difficult to feel more mature. ${ }^{3}$

\footnotetext{
${ }^{1}$ Rio Satria (Hakim Pengadilan Agama Sukadana). “Dispensasi Kawin Di Pengadilan Agama Pasca Revisi Undang-Undang Perkawinan. https://www.pa-sukadana.go.id/artikel-makalah/409-dispensasikawin-di-pengadilan-agama-pasca-revisi-undang-undang-perkawinan-oleh-rio-satria-16-10.html, accessed 02 September 2020.

${ }^{2}$ Pengadilan Agama Gresik. Sistem Informasi Penelusuran Perkara Pengadilan Agama Gresik. http:// sipp.pa-gresik.go.id/list_perkara/search_detail, accessed 10 September 2020.

${ }^{3}$ Willy Abraham dan Intan Aprilia. Pengadilan Agama Gresik Catat Janda Muda Berusia 22Tahun Tembus Angka 927 Orang dalam 1,5 Tahun. https://medan.tribunnews.com/2019/07/25/pengadilan-agamagresik-catat-janda-muda-berusia-22-tahun-tembus-angka-927-orang-dalam-15-tahun, accessed 10 September 2020.
} 
Based on the above background, it encourages the author to analyze and examine more deeply the application of the provisions for the age limit of marriage in the jurisdiction of the Gresik Religious Court.

\section{PROBLEM FORMULATION}

Implementation of Marriage Dispensation Regulation, to solve Marriage Age Limit Cases at The Gresik Religious Court.

\section{RESEARCH METHOD}

The method used in this research is socio-legal research, namely research that examines statutory regulations and is complemented by assessing the practice of dispensing marriage. To complete the study in this study, an investigation was carried out on the practice of using marriage dispensation that occurred in the Gresik Religious Court. Researchers use a statutory approach (statute approach). And Case Approach. This approach means that the authors use statutory regulations as the initial basis for conducting the analysis. The case approach is carried out by examining cases of marriage dispensation cases at the Gresik Religious Court. The review will focus on the ratio decidendi, namely the Judge's legal reasons to arrive at his decision. ${ }^{4}$

\section{DISCUSSION}

\section{Application of the Provisions on the Age Limit for Marriage Based on Article 7 of the Marriage Law on Applications for Marriage Dispensation at the Gresik Religious Court}

The Marriage Law regulates marriage's age limit in Article 7 Paragraph (1) states that marriage is only permitted if the male parties reach 19 (nineteen). Then in Article 7 Paragraph (2), it is said that in the case of deviations in Paragraph (1) of this article, dispensation may be requested from the Court or other official requested by the parents of the male or female party.

If analyzed further, this regulation on the age limit of marriage aims to prevent early marriage and is closely related to population and women's welfare issues. With age restrictions, the marriage law intends to manipulate the marriage rate, which leads to population growth.

Marriages that do not meet the requirements as regulated in Article 7 Paragraph (1) of the Marriage Law or underage can still be carried out by requesting dispensation from the Court. This dispensation takes the form of a permit as the basis for the Office of Religious Affairs (KUA) or civil registration for a husband and wife candidate. ${ }^{5}$

\footnotetext{
${ }^{4}$ Peter Mahmud Marzuki. (2005). Penelitian Hukum. Edisi Revisi. Jakarta: Prenadamedia Group, p. 158.

${ }^{5}$ Sonny Dewi Budiasih. (2018). Perkawinan Bawah Umur di Indonesia. Bandung: PT. Refika Aditama, p. 37.
} 
The dispensation is submitted in the form of a petition, as it is known that an application gives birth to a ruling and the basis for its filing because there is no dispute between the parties. Therefore the party can only consist of one person. The application for dispensation is not related to claims for rights. Still, with a process through the Court, civil procedure law that applies is in the form of legal regulations that determine how to guarantee the implementation of material civil law, which is marriage law. ${ }^{6}$

There were 77 (seventy-seven) cases of marriage dispensation applications in the Gresik Religious Court. In 2019 there was an increase of 20 (twenty) points to 97 (ninety-seven) cases, and in 2020 the first quartal of dispensation cases experienced a very significant increase of 160 (one hundred and sixty) cases. In the last two and a half years, the number of applications for dispensation of marriage registered at the Gresik Religious Court reached 334 (three hundred and thirty-four) cases. ${ }^{7}$ This indicates that applications for dispensation of marriage in the last two and a half years have increased.

In general, applications for dispensation of marriage at the Gresik Religious Court are caused by 2 (two) factors, namely Preventive and Curative. Preventive (preventive efforts) Is the prevention of adultery committed by children. The development of media (mainly electronic media) entering the Gresik district significantly affects teenagers' lifestyle and interactions in the neighbourhood. Their tendency to associate freely is higher. So hastening the marriage is an effort to overcome the dangers to adolescents from promiscuity. Even though they are not yet old enough, most parents who apply for marriage dispensation have reasons to be afraid that their children commit adultery or become pregnant before marriage. The reason is, they have been dating for a long time and are difficult to separate. They chose to marry off their children as a solution and applied for a Marriage Dispensation at the Gresik Religious Court.

Curative (effort or effort to cure) Namely the healing effort for parents who have no other choice but to give the child the option of getting married to cover up disgrace and save the child's status and guard against slander as a result of pregnancy outside of wedlock.

\section{Application of the Provisions on the Age Limit of Marriage on Filing of Applications for Marriage Dispensation at the Gresik Religious Court}

In discussing the age limit of marriage at the Gresik Religious Court, the answers needed to various questions are required. Is it true that the law's objectives can be distorted so that the age limit of marriage in Article 7 paragraph 1 of the Marriage

\footnotetext{
${ }^{6}$ Ibid., p. 37-38.

${ }^{7}$ Pengadilan Agama Gresik. Sistem Informasi Penelusuran Perkara Pengadilan Agama Gresik. http:// sipp.pa-gresik.go.id/list_perkara/search_detail, accessed 10 September 2020.
} 
Law cannot be applied; is it true that under certain circumstances, the law creates new complications, which of course means the law's ineffectiveness. The effectiveness of the law is also closely related to legal awareness and legal compliance with the community. ${ }^{8}$

Here will arise whether the age limit of marriage in the Gresik Religious Court jurisdiction has been useful and can be applied or vice versa? To answer this, there are three focus studies on the theory of legal effectiveness, including: ${ }^{9}$

1) Success in law enforcement, If legal norms are obeyed and implemented by the community and law enforcers, law enforcement is said to be useful or successful in its implementation;

2) Failure in its implementation that the stipulated legal provisions do not achieve their purpose or fail to implement them; and

3) The factors that influence it. The factors that contribute to or affect the law's implementation and application, the factors that influence can be assessed from:

a) Aspects of its success, including the substance of the law, culture, structure, and facilities; b) Aspects of failure. The factors that affect the default in law enforcement are obscure or unclear legal norms.

When analyzed from a study of legal effectiveness theory and related to the factors causing the application for marriage compensation at the Gresik Religious Court, paragraph 1 in Article 7 of the Marriage Law becomes less effective or cannot be fully applied to communities in the jurisdiction of the Gresik Religious Court.

\section{Examination of Marriage Dispensation Cases Based on Supreme Court Regulation Number 5 of 2019 Concerning Guidelines for Adjudicating Marriage Dispensation Requests}

The existence of this Perma is inseparable from the status of the Indonesian State, which is on the party of the Convention of the Child (Convention on the Rights of the Child), which affirms all actions concerning children carried out by social welfare institutions, state or private, courts; administrative authorities or legislative bodies, exercised in the interests of children. Automatically, Indonesia takes responsibility for its implementation, including child marriage or what is often termed underage marriage.

As one of the pinnacles of judicial power (in addition to the Constitutional Court), the Supreme Court considers that the dispensation of marriage, which is regulated

\footnotetext{
${ }^{8}$ Achmad Ali \& Wiwie Heryani. (2013). Menjelajahi Kajian Empiris Terhadap Hukum. Cet. II. Jakarta: Kencana Prenada Media Group, p. 131.

${ }^{9}$ Mutsla Sofyan Tasfiq. (2018). Dispensasi Kawin Pada Pasal 7 Undang-Undang Nomor 1 Tahun 1974 Yang Dimanfaatkan Untuk Kawin Sebab Hamil (Studi Pandangan Hakim di Pengadilan Agama Kabupaten dan Kota Malang Perspektif Efektivitas Hukum). Program Magister Al-Ahwal Al-Syakhshiyyah Pascasarjana. Malang: Universitas Islam Negeri Maulana Malik Ibrahim Malang, p. 47-48.
} 
based on the amendment to the new marriage law, has a significant impact on the process of judicial administration. Therefore, the Supreme Court has issued Supreme Court Regulation Number 5 of 2019 concerning Marriage Dispensation guidelines. ${ }^{10}$

Perma No. 5/2019 establishes several basic procedural law concepts for examining applications for dispensation of marriage that have never been previously determined. At least two things are the primary basis for the change in the substance of this Perma. This regulation discusses the procedures for marriage dispensation cases that apply to the religious courts and general courts, starting from the registration process, examination to legal remedies.

First, the Perma formally encourages examining cases of marriage dispensation with one Judge (single Judge). A single judge's application is accustomed to carrying out involuntary cases or petitions in the general court environment. In contrast, in the climate of religious courts, case examination is always carried out by the Panel of Judges even though the case is in the form of a petition.

Second, substantially this Perma wants marriage dispensation examination to be carried out comprehensively. Analysis of marriage dispensation must pay attention to various factors for the child's benefit as a prospective bride, ranging from health factors, social economy, and culture, even if it must be seen from the element of whether or not there is violence in the form of coercion. So that the request for dispensation of marriage does not seem "easy" in its licensing with the static consideration of the argument that "Rejecting immodality is more important than attracting benefit."

In examining cases of marriage dispensation, according to the provisions of Article 11 of Perma No. 5/2019, judges are required to use language and methods that are easy for the child to understand and understand, plus the provision that judges and clerks examine children, namely children who are being requested for dispensation or to prospective wives/husbands who are still categorized as children, do not need to wear court attributes, namely a gown and tie for the Judge and a coat for the substitute clerk.

The Judge is obliged to advise the applicant, the child, the prospective husband/ wife, and the parents/guardian of the future husband/wife must consider. This advice aims to provide education and consideration for the parties, especially children, regarding underage marriage's dispensation. According to the provisions of Article 12 of Perma No. 5 of 2019, there are at least 5 (five) things that the Judge must convey to the parties as advice regarding marriage and the risks to be faced after underage marriage itself, including the following:

1) Possibility of cessation of education for children;

${ }^{10}$ Sugiri Permana dan Ahmad Zainal Fanani. (2019). Dispensasi Kawin dalam Hukum Keluarga di Indonesia, Kajian atas Norma dan Praktik Hukum Acara Pasca Disahkannya UU No. 16 Tahun 2019 dan PERMA No. 5 Tahun 2019. Surabaya, p. 3. 
2) Continuity of children in taking the 12-year compulsory education;

3) The reproductive organs of the child are not ready;

4) Economic, social, and psychological impacts of children; and

5) Potential disputes and domestic violence.

In examining a marriage dispensation trial, a single judge must pay attention to the child's psychological condition, health, and readiness to marry and build a household life. The Judge must also ensure that the child knows and agrees to the Court's request regarding the marriage plan. There is no coercion from any party, be it psychological, physical, and sexual or economic coercion against the child/or the child's family. To marry and marry off children.

Several things must be considered by judges who are in the best interests of the child. Furthermore, in the examination, the Judge takes into account the best interests of the child by:

1) Studying thoroughly and carefully the applicant's petition;

2) Checking the legal position of the applicant;

3) Exploring the background and reasons for the child's marriage;

4) Digging up information related to whether there is a marriage obstacle;

5) Obtaining information related to the understanding and consent of the child to be married;

6) Taking into account the age difference between the child and the prospective husband/wife;

7) Hearing the statement of the applicant, children, prospective husband/wife, and parents/guardians of the future husband/wife;

8) Taking into account the psychological, sociological, cultural, educational, health, economic conditions of children and parents, based on recommendations from psychologists, doctors/midwives, professional social workers, social welfare workers, the Integrated Service Center for the Protection of Women and Children (P2TP2A) or the Protection Commission Indonesian/Regional Children (KPAI/ KPAD); consider whether there are elements of psychological, physical, sexual and/or economic coercion; and

9) Ensuring parents' commitment to take responsibility for children's economic, social, health, and educational issues.

\section{Judges' Considerations in Examining and Stipulating Marriage Dispensation Cases at the Gresik Religious Court}

The forms of determination of Marriage Dispensation at the Gresik Religious Court will be analyzed by taking 2 (two) samples each based on the decisions that were granted and those that were rejected, as follows: 


\section{Determination of the granted marriage dispensation}

\section{Determination Number 0036/Pdt.P/2020/PA.Gs}

Based on their application letter, the Petitioners registered at the Registrar's Office of the Gresik Religious Court Number 0036/Pdt.P/2020/PA.Gs have put forward things that applied for marriage dispensation because the local KUA rejected the applicant's child marriage because of the child's age. The applicants who have not met the marriage age limit as stipulated in the Marriage Law are still 15 (fifteen) years old.

The Petitioners argued that the marriage was essential to continue because the Petitioners' child (prospective wife) had currently been in a close relationship (dating) with her future husband for 6 (six) months, so the Petitioners were very worried that it would cause more significant harm if not married immediately

\section{Trial examination, as follows:}

The Judge has advised the Petitioners, the children of the applicants, the prospective husbands of the applicants' children, and the future husbands' parents regarding the provisions on the age limit for marriage until the child turns 19 and its implications. however, the Judge's advice was not successful because the Petitioner argued that there had been matters involving a marriage emergency

The Judge examined the evidence of letters and witnesses presented and presented by the applicants. The Judge also heard the statements of the applicants 'children and their future husbands. The Judge assessed that the applicants' children had shown maturity and reached maturity referred to in Islamic law. because the petitioners 'child is already mature and according to the Judge's judgment before the trial, she is mature enough physically and mentally to become a wife and now loves each other and has a close relationship between the applicant's children and her future husband, the petitioners' concern if the child is not immediately being married to more madlarat than the maslahat is quite reasonable according to the law

\section{Judges' considerations, as follows:}

Based on these facts and considerations, the Judge believed that the petitioners 'petition to marry off their children were seen as having greater maslahah and benefits than mafsadat, following fiqhiyyah qaidah, the Judge believed that the arguments of the petitioners' petition were sufficiently grounded and based on law. Therefore their petition should be granted.

\section{Analysis of Determination Number 0036/Pdt.P/2020/PA.Gs}

The Judge has advised the Petitioners, the Petitioners 'children, the prospective husbands of the Petitioners' children, and the parents of the future husbands regarding the provisions regarding the age limit for marriage until the child turns 19 years old, and the impact on:

a) Possible cessation of children's education; 
b) Continuity of children taking the 12-year compulsory education;

c) Matters related to child reproduction;

d) Potential for disputes and domestic violence;

However, the Judge's advice was unsuccessful because the Petitioner argued that marital emergency matters. The Judge's recommendation is following Article 12 of Perma No. 5/2019.

The Judge considers the prospective husband and wife's health and psychological conditions based on witnesses' evidence and testimony. The future wife is biologically mature and ready to become a wife, while the husband already has income from his job. The Judge argues that the prospective husband and wife are prepared to become husbands and are biologically mature enough to carry out their obligations as a wife when married. The petitioners' concern that if the child is not married off, there will be more madlarat than the maslahat is quite reasonable according to the law. The judges' considerations are following Article 14 of Perma No. 5/2019.

The petitioners' petition has sufficient grounds following Article 7 paragraph (2) of the Marriage Law because of the considerations mentioned above. The Judge gives dispensation to the applicant's child to marry a prospective male husband, and this stipulation is based on statutory regulations and laws. Islam related to this petition case.

Judges considerations are following Perma No. 5/2019 in granting applications for dispensation of marriage Number 0036/Pdt.P/2020/PA.Gs are basically as follows:

1) The Judge has advised the Petitioners, the Petitioners' children, the prospective husband's children, and the parents of the future husbands regarding the provisions on the age limit for marriage until the child turns 19 years old, along with its consequences. However, the Judge's advice was not successful, because the Petitioners postulate that there have been cases of marriage emergency;

2) The Petitioners 'children have shown their maturity and have reached maturity as referred to in Islamic law, are already mature, and according to the Judge's judgment before the trial, they are mature enough physically and mentally to become a wife, so the Petitioners' worries if the child is not married off will be more its madlarat rather than maslahat is lawful enough;

3) There is no mahram relationship, and there is no sexual relationship and other causes that prevent them from getting married. The Panel of Judges believes that the Petitioners' petition to marry off their children is seen as having greater maslahah and benefits than mafsadat.

\section{Determination Number 0004/Pdt.P/2020/PA.Gs}

Based on his application letter, the applicant registered at the Registrar's Office of the Gresik Religious Court Number 0004/Pdt.P/2020/PA.Gs has put forward things 
that applied for marriage dispensation because the local KUA rejected the applicant's child marriage due to the age of the applicant's child those who have not met the age limit of marriage as stipulated in the Marriage Law, which is still 18 (eighteen) years old.

The Petitioner argued that the marriage was essential to continue because the Petitioner's (Wife Candidate) child had currently been in a close relationship (dating) with her future husband for 1 (one) year, even based on the medical examination now the prospective wife (the Petitioner's child) was pregnant. Five months due to the biological relationship between the Petitioner's child and her future husband, the Petitioner is very worried that it will cause more significant harm if not married immediately.

\section{Trial examination, as follows:}

The Judge has advised the Petitioners, the children of the applicants, the prospective husbands of the applicants' children, and the future husbands' parents regarding the provisions on the age limit for marriage until the child turns 19 and its implications. however, the Judge's advice was not successful because the Petitioner argued that there had been matters involving a marriage emergency

The Judge has examined the evidence of letters and witnesses presented and presented by the applicants. The Judge also heard the statements of the applicants' children and their future husbands. The Judge assessed that the applicants' children had shown maturity and reached maturity referred to in Islamic law because the Petitioners' children were aged and obeyed. Judge's assessment before the trial that she is mature enough physically and mentally to become a wife and now loves each other and has a close relationship between the Petitioner's child and her future husband, even the Petitioner's child is now five months pregnant, so the Petitioner's concern that if the child is not immediately married will be more madlarat than maslahat is quite reasonable according to law.

\section{Judges' considerations, as follows:}

Based on these facts and considerations, the Judge believed that the petitioners 'petition to marry off their children were seen as having greater maslahah and benefits than mafsadat, following fiqhiyyah principles arguments of the petitioners' petition were sufficiently grounded and legally based. Therefore their petition should be granted

\section{Analysis of Determination Number 0004/Pdt.P/2020/PA.Gs}

The Judge accepts the purpose and objective of the petitioners' petition, which is an application for dispensation of marriage for the child of the applicant who will marry off his child who has not reached the legal age of marriage, which is 19 (nineteen) years old. The Gresik Religious Court Judge has the authority to adjudicate 
the case for the dispensation marriage application because based on the evidence that the applicant presents in the form of a photocopy of the Identity Card which has been matched with the original and is suitable, the applicant resides in the jurisdiction of the Gresik Religious Court.

The Judge has advised the Petitioners, the Petitioners 'children, the prospective husbands of the Petitioners' children, and the parents of the future husbands regarding the provisions regarding the age limit for marriage until the child turns 19 years old, and the impact on:

a) Possible cessation of children's education;

b) Continuity of children taking the 12-year compulsory education;

c) Matters related to child reproduction;

d) Potential for disputes and domestic violence;

However, the Judge's advice was unsuccessful because the Petitioner argued that marital emergency matters. The Judge's recommendation is following Article 12 of Perma No. 5/2019.

Based on other written evidence, the Judge confirmed that the child of the applicant/prospective wife was 18 (eighteen) years old and was still under age permitted to marry as required by Article 7 of the Marriage Law that marriage is only allowed if the parties have reached 19 (nineteen) years old.

Judges consider and assess the prospective husband and wife's health and psychological conditions based on witnesses' evidence and testimony. Because the Petitioner's child is already aged and according to the judges of the Panel of Judges before the trial, he is mature enough both physically and mentally to become a wife and now loves each other and has a close relationship between the Petitioner's child and her future husband, even the Petitioner's child is now five months pregnant. Therefore, the Petitioners' concern that if the child is not married off, there will be more madlarat than the maslahat is quite reasonable according to the law. The judges' considerations are following Article 14 of Perma No. 5/2019.

The petitioners' petition has sufficient grounds following Article 7 paragraph (2) of the Marriage Law because of the considerations mentioned above. The Judge gives dispensation to the applicant's child to marry a prospective male husband, and this stipulation is based on statutory regulations and laws. Islam related to this petition case.

There are four considerations of Judges at the Gresik Religious Court in granting a dispensation to marry in case number 0004/Pdt.P/2020/PA.Gs, namely:

1) The Judge has advised the Petitioners, the Petitioners' children, the prospective husband's children, and the parents of the future husbands regarding the provisions on the age limit for marriage until the child turns 19 years old, along 
with its consequences. However, the Judge's advice was not successful, because the Petitioners postulate that there have been cases of marriage emergency;

2) The Petitioners 'children have shown their maturity and have reached maturity as referred to in Islamic law, so the Petitioners' worries if the child is not married off will be more its madlarat rather than maslahat is lawful enough;

3) There is no mahram relationship, and there is no sexual relationship and other causes that prevent them from getting married; and

4) The Panel of Judges believes that the Petitioners' petition to marry off their children is seen as having greater maslahah and benefits than mafsadat.

In this case, the parents, if they are not immediately married, it will lead to madlarat or acts that are prohibited by religion, this consideration focuses more on whether the maslahah is more significant and its benefits than madlarat if it is not immediately married. The judges' considerations are following Perma No. 5/2019.

\section{Determination of the Rejected Marriage Dispensation Determination Number 0083/Pdt.P/2020/PA.Gs}

Based on their application letter, the Petitioners registered at the Registrar's Office of the Gresik Religious Court Number 0083/Pdt.P/2020/PA.Gs have put forward things that applied for dispensation of marriage because the local KUA rejected the applicant's child marriage because of the child's age applicants who have not met the age limit of marriage Marriage Law, namely still 14 (fourteen) years old.

The Petitioners argued that the marriage was essential to continue because the Petitioners' child (prospective wife) had currently been in a close relationship (dating) with her future husband for 2 (two) years, so the Petitioners were very worried that it would cause more significant harm if not married immediately

\section{Trial examination, as follows:}

The Judge has advised the Petitioners, the children of the applicants, the prospective husbands of the applicants' children, and the future husbands' parents regarding the provisions on the age limit for marriage until the child turns 19 and its implications. however, the Judge's advice was not successful because the Petitioner argued that there had been matters involving a marriage emergency

The Judge has examined the evidence of letters and witnesses presented and presented by the applicants. The Judge also heard the statements of the applicants' children and their future husbands. Based on this, the Judge did not find facts in the trial about an emergency condition that underlies the immediate marriage.

\section{Judges' considerations, as follows:}

Whereas, based on the Petitioner's evidence, there were no facts found in the Court about an emergency condition that underlies the marriage's immediate 
implementation. Because the Petitioners cannot prove their petition's arguments, the Petitioners' petition to ask for dispensation to marry their children must be rejected.

\section{Analysis of Determination Number 0083/Pdt.P/2020/PA.Gs}

The Judge accepts the purpose and objective of the petitioners' petition, which is an application for dispensation of marriage for the child of the applicant who will marry off his child who has not reached the legal age of marriage, which is 19 (nineteen) years old.

Based on testimony from witnesses, no facts were found in the trial about any emergency conditions that underlie the immediate marriage, even though he was not yet of age following Article 7 of the Marriage Law. The judges' considerations are following Article 14 of Perma No. 5/2019.

Due to the considerations mentioned earlier, the petitioners 'petition was not sufficiently grounded following Article 7 paragraph (2) of the Marriage Law. The Judge rejected the petitioners' request for dispensation of marriage.

Judges are following Perma No. 5/2019 in rejecting dispensation of marriage in case number 0083/Pdt.P/2020/PA.Gs, there are two main things, namely:

1) The Judge has advised Petitioner I and Petitioner II, children of Petitioner I and Petitioner II, prospective husbands of Petitioners I and Petitioner II, and parents of future husbands regarding the age provisions limit marriage until the child turns 19 years old. The impact will be, but the Judge's advice was unsuccessful because the Petitioner argued that there had been cases of marriage emergency.

2) Concerning the evidence presented by the Petitioner, the Judge did not find facts in the trial regarding an emergency condition that underlies the immediate implementation of the marriage.

\section{Determination Number 0094/Pdt.P/2020/PA.Gs}

Based on their application letter, the Petitioners registered at the Registrar's Office of the Gresik Religious Court Number 0094/Pdt.P/2020/PA.Gs have put forward things that applied for marriage dispensation because the local KUA rejected the applicant's child marriage because of the child's age. The applicants who have not met the marriage age limit are still 17 (seventeen) years old as stipulated in the Marriage Law.

The Petitioners argued that the marriage was essential to continue because the Petitioners' child (prospective wife) had currently been in a close relationship (dating) with her future husband for 4 (four) years, so the Petitioners were very worried that it would cause more significant harm if not married immediately

\section{Trial examination, as follows:}

The Judge has advised the Petitioners, the children of the applicants, the prospective husbands of the applicants' children, and the future husbands' parents 
regarding the provisions on the age limit for marriage until the child turns 19 and its implications. however, the Judge's advice was not successful because the Petitioner argued that there had been matters involving a marriage emergency.

The Judge has examined the evidence of letters and witnesses submitted and presented by the applicants. The Judge also heard the statements of the applicants' children and their future husbands. Based on this, the Judge did not find facts in the trial about an emergency condition that underlies the immediate marriage.

\section{Judges' considerations, as follows:}

There were no facts found in the Court about an emergency condition that underlies the marriage's immediate implementation, the Petitioners' petition to ask for dispensation to marry their children must be rejected.

\section{Analysis of Determination Number 0094/Pdt.P/2020/PA.Gs}

The Judge accepts the purpose and objective of the petitioners' petition, which is an application for dispensation of marriage for the child of the applicant who will marry off his child who has not reached the legal age of marriage. Based on testimony from witnesses, no facts were found in the trial about any emergency conditions that underlie the immediate marriage, even though he was not yet of age following Article 7 of the Marriage Law. The judges' considerations are following Article 14 of Perma No. 5/2019.

Due to the considerations mentioned earlier, the petitioners 'petition was not sufficiently grounded following Article 7 paragraph (2) of the Marriage Law. The Judge rejected the petitioners' request for dispensation of marriage.

Judges of the Gresik Religious Court reject marriage dispensation in case number 0094/Pdt.P/2020/PA.Gs, there are two main things, namely:

1) The Judge has advised Petitioner I and Petitioner II, children of Petitioner I and Petitioner II, prospective husbands of Petitioners I and Petitioner II, and parents of future husbands regarding the age provisions limit marriage until the child turns 19 years old. The impact will be, but the Judge's advice was unsuccessful because the Petitioner argued that there had been cases of marriage emergency.

2) Concerning the evidence presented by the Petitioner, the Judge did not find facts in the trial regarding an emergency condition that underlies the immediate implementation of the marriage.

\section{Judges' Evaluation Factors in Granting or Rejecting Applications for Marriage Dispensation}

Based on the analysis of the above considerations, the authors found that various factors were granted or rejected a marriage dispensation application, including: For cases that are granted, as follows 
1) The existence of an emergency element of marriage emergency becomes a measure of the presence of an emergency element, namely as follows:

a. Pregnant

The Judge grants the marriage dispensation case if there is a condition in which the applicant's child or the prospective wife's child is pregnant. However, there is a law that states that the minimum age limit for marriage is 19 years. This is in line with ushul fiqh's rules, which reads: "An emergency allows something that is forbidden." The Judge grants the case of marriage dispensation in case of an emergency;

The State of emergency is if you arrive at a limit where you don't do what is forbidden (haram). This condition allows the violation of the prohibition. The breach was carried out because it safeguarded five main things in Islam, namely protecting religion, guarding the soul, maintaining reason, guarding descent, and protecting property. For example, it is permissible for someone to eat a carcass when they are hungry. If they don't eat it, then that person will die. This ability only makes a person able to survive or eat in moderation. This is the same as the decision of the panel of judges which granted the application for marriage dispensation because the child was pregnant before marriage;

The fulfilment of the petitioners' petition is nothing but for the benefit. Because if the petitioners' plea is not granted, the impact will be enormous. The child will give birth to a child without a father, and the parents will get pressure and gossip from people around them for not being able to educate their children.

b. Intercourse with children

The association of children who is very worried is the Judge's judgment in making a decision.

A petition with such a condition as the applicant's child does not automatically grant it, but the Judge is looking for evidence to prove that the applicant's children's association is very worrying. And if it is true, this is where the role of the Judge and the law is needed by the community in providing the best facilities and solutions to problems that occur in society, because if it is not granted, the child's actions will become gossip that makes children and parents feel depressed.

The decision of the Judge who granted the request for dispensation of marriage was nothing but giving an exact status to the child he was carrying, saving the applicant's child from adultery that would occur continuously, and preventing the threat of harassment from the wider community.

For cases that were rejected, as follows

The Judge's assessment factor in the case that the marriage dispensation petition is not granted, namely because in the marriage dispensation applicant's application 
after being examined, there is no emergency element found and cannot prove the reasons for his application in Court. The request was filed only because of personal or group interests, for example, only because of parents' wishes alone. Therefore, under the conditions above, the Religious Court does not grant the request for dispensation of marriage to marry. Even though he is faced with complex issues, judges must be selective in deciding marriage dispensation cases. There is no stigma that marriage dispensation ignores household harmony's constituent elements, namely physical and psychological maturity. Judges should pay attention to the following five aspects:

First, an urgent condition immediately requires handling from the Judge. For example, getting married pregnant, or there is a strong indication that the prospective bride has committed adultery but has not yet gotten pregnant. Another urgent condition is the difficulty of accessing public services so that there are married couples who are married by religion but are still underage.

Second, a statement of readiness and willingness from the prospective bride. The future bride must understand her reproductive health. Because in marriage, conception can occur after sexual intercourse. When examining the request posita, the panel conducts an in-depth study of the prospective bride's information. It may be that the decision to marry at a young age is not based on his own will, but because of the parents' interests, both because of religious and economic reasons.

Third, an assessment of the quality of parents or guardians. In pregnant marriage, the Judge can explain that the prospective bride and groom are not ready psychologically and economically. However, due to compelling conditions, they were married off, with a note that there must be guidance from adults to live a household life to not lead to divorce. Meanwhile, in the context of the concern that the child is committing adultery, the parents must prove their concern. If not, then it should be rejected.

Fourth, the prospective groom's commitment to carry out his responsibilities as head of the household, especially in the economic sector. In the concept of fiqh and the Marriage Law, men have a significant obligation. If they are underage, according to Isroqunnajah and Rusmulyani, at least there is a guarantee that the prospective groom is capable of working. So that it doesn't add to the unemployment list.

Fifth, Physical maturity, this criterion is the easiest to prove. For women, it has been proven that menstruation and men can produce sperm. In the case of pregnant marriage, this indicator will be easy to assess.

\section{CLOSING}

\section{Conclusion}

The application of the provisions for the age limit of marriage stipulated in the UUP for applications for dispensation of marriage at the Gresik Religious Court, if it is 
analyzed from a study of the theory of legal effectiveness and is related to the factors causing the application for dispensation of marriage at the Gresik Religious Court, the provisions for the age limit of marriage are less effective or cannot be applied. Entirely towards the community in the jurisdiction of the Gresik Religious Court. This is indicated by the high number of applications for dispensation of marriage at the Gresik Religious Court. The Judge's consideration in examining the case of the application for marriage dispensation at the Gresik Religious Court is following the procedures stipulated in Perma No. 5/2019, the Judge's consideration focuses more on whether the maslahah is more significant and its benefits than the madlarat if it is not immediately married off, basically the applicant's concern it is still vague and not yet concrete and even speculative. Therefore, the parties can always postpone their child's marriage until the child is old enough as stipulated in the UUP. However, there is no statutory norm that explains the urgent/emergency criteria. It is different from the Judge's consideration of submitting a request for Marriage Dispensation due to the prospective wife/woman being pregnant. This condition can be categorized as very urgent to carry out marriage immediately.

\section{Recommendation}

Parents should better supervise, control, and understand their children to be careful in socializing, especially in communicating with the opposite sex, to not fall into promiscuity, which will harm themselves. This effort is expected to reduce applications dispensation of marriage at the Gresik Religious Court. To the Judges at the Gresik Religious Court to examine and determine cases of the dispensation of marriage to prioritize children's rights as regulated in the Child Protection Law, to reduce the number of underage marriages in the jurisdiction of the Gresik Religious Court.

\section{REFERENCES}

HIR (Herziene Indonesisch Reglement).

RBG (Reglement Buitengewesten).

Undang-Undang Nomor 1 Tahun 1974 tentang Perkawinan.

Intruksi Presiden Nomor 1 Tahun 1991 tentang Kompilasi Hukum Islam.

Undang-Undang 18 Tahun 2009 tentang Kekuasaan Kehakiman.

Undang-Undang Nomor 35 Tahun 2014 tentang Perubahan Atas Undang-Undang Nomor 23 tahun 2002 tentang Perlindungan Anak.

Undang-Undang Nomor 16 Tahun 2019 tentang Perubahan Atas Undang-Undang Nomor 1 Tahun 1974 tentang Perkawinan.

Peraturan Mahkamah Agung Nomor 5 Tahun 2019 tentang Pedoman Pedoman Mengadili Permohonan Dispensasi Kawin. 
Achmad Ali \& Wiwie Heryani. (2013). Menjelajahi Kajian Empiris Terhadap Hukum. Cet. II. Jakarta: Kencana Prenada Media Group.

Mutsla Sofyan Tasfiq. (2018). Dispensasi Kawin Pada Pasal 7 Undang-Undang Nomor 1 Tahun 1974 Yang Dimanfaatkan Untuk Kawin Sebab Hamil (Studi Pandangan Hakim di Pengadilan Agama Kabupaten dan Kota Malang Perspektif Efektivitas Hukum). Program Magister Al-Ahwal Al-Syakhshiyyah Pascasarjana. Malang: Universitas Islam Negeri Maulana Malik Ibrahim Malang.

Pengadilan Agama Gresik. Sistem Informasi Penelusuran Perkara Pengadilan Agama Gresik. http://sipp.pa-gresik.go.id/list_perkara/search_detail

Peter Mahmud Marzuki. (2005). Penelitian Hukum. Edisi Revisi. Jakarta: Prenadamedia Group.

Rio Satria (Hakim Pengadilan Agama Sukadana). "Dispensasi Kawin Di Pengadilan Agama Pasca Revisi Undang-Undang Perkawinan. https://www.pa-sukadana. go.id/artikel-makalah/409-dispensasi-kawin-di-pengadilan-agama-pasca-revisiundang-undang-perkawinan-oleh-rio-satria-16-10.html

Sonny Dewi Budiasih. (2018). Perkawinan Bawah Umur di Indonesia. Bandung: PT. Refika Aditama.

Sugiri Permana dan Ahmad Zainal Fanani. (2019). Dispensasi Kawin dalam Hukum Keluarga di Indonesia, Kajian atas Norma dan Praktik Hukum Acara Pasca Disahkannya UU No. 16 Tahun 2019 dan PERMA No. 5 Tahun 2019. Surabaya.

Willy Abraham dan Intan Aprilia. Pengadilan Agama Gresik Catat Janda Muda Berusia 22Tahun Tembus Angka 927 Orang dalam 1,5 Tahun. https://medan.tribunnews. com/2019/07/25/pengadilan-agama-gresik-catat-janda-muda-berusia-22-tahuntembus-angka-927-orang-dalam-15-tahun 